\title{
ЦАХИЛГААН СТАНЦЫН ХАЯГДАЛ ҮНС, ҮНСНИЙ ХЭРЭГЛЭЭ, ҮНСИЙГ МАНАЙ УЛСАД АШИГЛАХ БОЛОМЖ
}

\author{
Ж.ТэмҮүжин \\ ШУА, Хими, Хими-Технологийн ХУрээлэн
}

\section{Товч агуулга}

Цахилгаан станизыэ хаягдал үнсний төрөл, хими, эрдэс зүйн найрлага болон гадаад бүтиийн ониялогыг судлав. Цахилгаан станц̧ьлн хаягдал үнс нь барилга, хими, иинэ болон байгаль орчны хамгааллын чиглэлээр ашиглаж болох хэрэгиээт түүхий эд юм. Үнс нь инэнхидээ хөнгөн цุагаант цุахиураас тогтсон бөмбөлөг хэлбэрийн гадаад бүтэцтээй байдаг. Манай оронд хаягдал үнсийг ашиглах шинэ боломж байгааг өөрсдийн хийж буй судалгааны үндсэн дээр тодорхойлов.

\section{ОРШИЛ}

Үнсийгорганикагуулсаннэгдлийншат алтийнүлдэгдэлгэжерөнхийдньүзэжболно. Үнсийгхүнтөрөлхтөнмашэртдээрүеэсаши глажбайсанмэдээбайдаг.ЭртнийРомхотод 2000 гаруйжилийнтүүхтэйархитекторынх осгүйдурсгалболсонКолизейцэнгэлдэххү рээлэнболонэртнийбурхдынөргөөболохП антеоныгбарихдаамөнгалтуулынүнсашиг лажбайсанбайна.Эдгээрбарилгуудньонца гийнуртадбүрмөсөнэвдэрчнуралгүйодоог хүртэлбайжбайгааньгалтуулынүнс, шохо йболонголынэлсийгашиглажүйлдвэрлэсэ нэртнийРомынбетонньонцгойбатбөхийн үзүүлэлтэйбайсныбаталгааюм [1].Дээрхи жишээнээс харахад үнсийг эрт дээр үеэс эхлэн тодорхой хэмжээгээр ахуйн болон үйлдвэрлэлийн зориулалтаар ашиглаж байжээ. Үнс нь шаталтийн үлдэгдэл хаягдал боловч энэхүу хаягдлын хэмжээ нь их хэмжээний үйлдвэрлэл явуулах түвшинд байгаагүй бололтой. Эрт үеэс ашиглаж байсан үнс нь ч мөн хүний үйл ажиллагаанаас бий болоогүй байсан байна. Хүний үйл ажиллагаанаас бий болсон үнсийг нүүрсийг зориудаар түлж байсан үетэй холбож үзэх нь зүйтэй юм.

Нүүрс нь шатах түлш хэлбэрээр эртний Грек болон Ромын эзэнт гүрний үеэс хэрэглэгдэж эхэлсэн байна. Эртний Грекийн философич Теофрастус (Theophrastus) нь манай эриний өмнөх 4-р зуунд гарсан “Чулууны тухай” зохиолдоо шатдаг түүхий эдийг түлш болгон ашиглаж байсан тухай дурдсан байдаг байна [2].

Хүний ухаант үйл ажиллагаанаас ҮҮдсэн нүүрсний хаягдал үнсний хэмжээ хүн төрөлхтөн цахилгаан эрчим хүч ашиглаж эхэлснээс хойш үлэмж хэмжээгээр нэмэгдсэн гэж үзэж болохоор байна. Дэлхий дахинд ажиллаж буй цахилгаан станцууд нь шатах түлшийг ашиглан эрчим хүч үйлдвэрлэдэг. Нүүрс нь дэлхий дээрхи эрчим хүчний үйлдвэрлэлийн голлох түүхий эд юм. Дэлхийн эрчим хүчний үйлдвэрлэлд эзэлж буй түлшний хэмжээг харуулав.

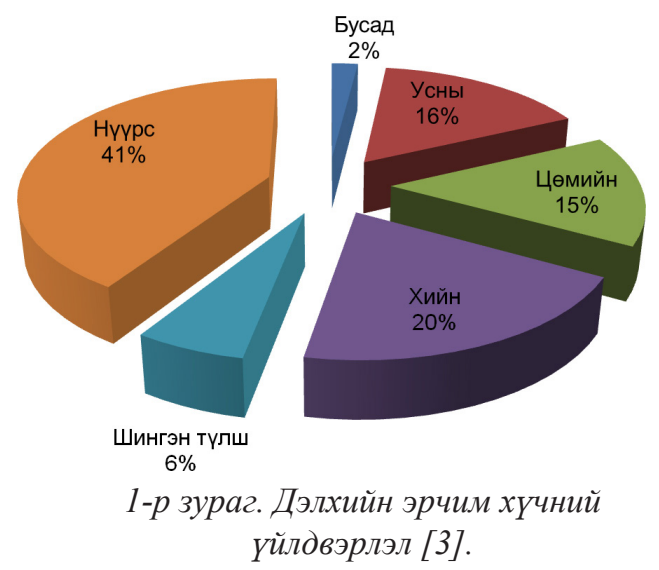


Нүүрсийг эрчим хүчний үйлдвэрлэлд ашиглах нь улс орон бүрд өөр өөр байдаг.
Нүүрсийг эрчим хүчний үйлдвэрлэлд ашиглах хэмжээг 1-р хүснэгтэд харуулав.

Хуснэгт 1

Улс орнуудын нүҮрсийг эрчим хүчний үйлдвэрлэлд ашиглаж буй хэмжээ

\begin{tabular}{|c|c|c|}
\hline Монгол $90 \%$ & Польш $93 \%$ & БНХАУ $81 \%$ \\
\hline Өмнөд Африк $94 \%$ & Израйл $71 \%$ & Казахстан $70 \%$ \\
\hline Австрали $76 \%$ & Грек $55 \%$ & Чех $62 \%$ \\
\hline Энэтхэг $68 \%$ & АНУ $49 \%$ & Герман $49 \%$ \\
\hline
\end{tabular}

Урьдчилсан тооцоогоор нүүрснээс эрчим хүч үйлдвэрлэх хэмжээ дэлхий даяар буурахгүй төлөвтэй байгаа бөгөөд 2030 онд нийт эрчим хүчний 44\%-ийг нүүрсийг ашиглангаргахаарбайна.Нүүрсийгашиглаж гаргасан эрчим хүч нь бусад эх үүсвэрээс гаргасан эрчим хүчтэй харьцуулахад харьцангуй хямд учраас байгаль орчны бохирдлыг үүсгэж буй шалтгаанаар ойрын болон дундын ирээдүйд дулааны цахилгаан станцын ашиглалтыг бүрэн хэмжээгээр зогсоох боломжгүй юм. Үнс нь нүүрсэнд агуулагдах, шатдаггүй эрдэс хольцын шатаалтын үед үүссэн бүтээгдэхүүн юм. Нүүрсэнд агуулагдах эрдэсүүд нь төрөл бүрийн бүлэгт хамаарах бөгөөд голчлон силикат, оксигидроксидоос тогтохоос гадна сульфат, карбонат, сульфид болон фосфат, үндсэн элемент, хлорид болон бусад эрдэсүүд бас агуулагдаж болно. Нүүрсэнд агуулагдах эрдэс нь хэмжээгээрээ: силикат $>$ карбонат $>$ оксигидроксид $>$ сульфид $\geq$ сульфат $>$ фосфат $>$ бусад нэгдэл гэсэн ерөнхий дараалалтай байдаг байна. Нүүрсэнд агуулагдах үндсэн эрдэсүүдэд кварц, каолинит, иллит, кальцит, пирит, плагиоклаз, Калийн хээрийн жонш, гипс багтах бөгөөд төмрийн оксигидроксид, сульфат, доломит, анкерит, сидерит зарим тохиолдолд агуулагддаг. Бусад хольцууд нь маш бага хэмжээтэй хольц гэж тооцогддог. Нүүрсэнд агуулагдах эрдэс хольц нь нүүрсийг ашиглах үеийн үйлдвэрлэл, технологи болон байгаль орчны хамгааллын чиглэлээр үүсэж болох асуудлуудтай ихээр холбогдож байдаг. Нийтдээ нүүрсэнд агуулагдаж байдаг 125-аас их тооны эрдэсүүд байдгаас 100 гаруй нь маш бага буюу, бага хэмжээгээр агуулагддаг байна[4].

Дэлхий нийтэд эрчим хүчний хэрэглээ өсөж байгаагаас дулааны цахилгаан станцаас гардаг хаягдал үнс нь хамгийн их хэмжээгээр хуримтлагддаг хаягдлын тоонд багтдаг. Цахилгаан станц ажиллах үед утаагаар зөөгдөн цахилгаан шүүлтүүрт хураагдаж буй хэсгийг үнс (fly ash), харин шатаах зуухны ёроолд үлдсэн том ширхэглэлтэй хэсгийг шаарга (bottom ash) гэж хуваадаг. Иймээс үнс нь аморфжилт ихтэй бөмбөлөг хэсгээс тогтдог бол шаарга нь талст бүтэц ихтэйгээс гадна бөмбөлгөн бүтэц багатай юм. Дулааны цахилгаан станцаас гарах үнсний ерөнхий зарчмыг 2-р зурагт үзүүлэв.

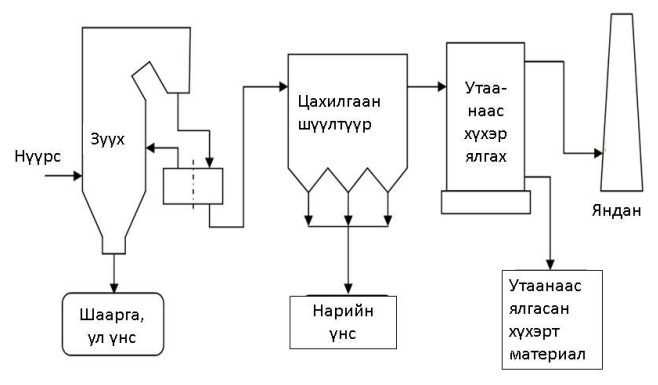

2-р зураг. Дулааны ичахилгаан станцаас үнс гарах ерөнхий зарчим

Цахилгаан шүүлтүүрийн нарийн ширхэглэлтэй үнс нь станцын гаргаж буй нийт үнсний 70-аaс илүу хувийг эзэлдэг гэж үздэг. Ерөнхийд нь цахилгаан станцын шатаалтын хаягдлыг нүүрсний шаталтын дагавар бүтээгдэхүүн (coal combustion 
byproducts) гэж нэрлэдэг бөгөөд үүнд нь үнс болон шааргын аль аль нь багтдаг. Үнс нь гадаад хэлбэрээрээ хар саарал өнгөтэй, нарийн ширхэглэттй байдаг бөгөөд дундаж хэмжээгээр авч үзвэл нийт үнсний 80-аас илүү хувь нь 100 микроноос нарийн

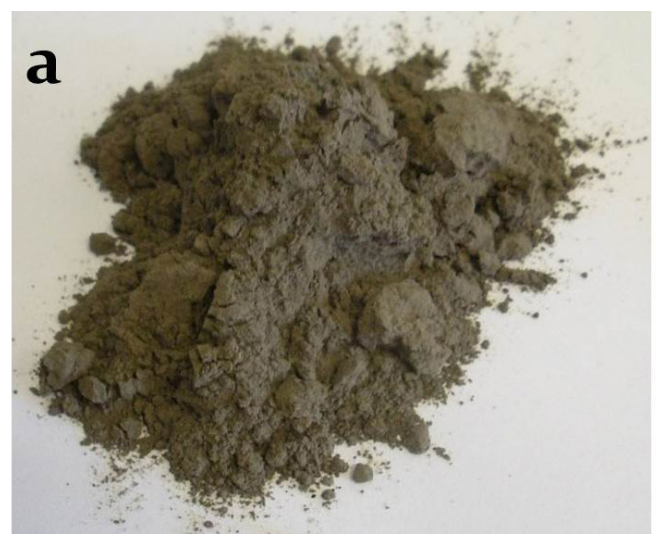

ширхэглэлтэй байдаг. Станцаас ялгарах үнсний ердийн зургийн аппаратаар авсан болон өндөр нөрийвчлалтай электрон микроскопоор авсан зургаас (3-p зураг) үнсний бүтэц нь ердийн нүдээр харснаас ямар ялгаатай болохыг харж болно.

3-р зураг. Цахилгаан станцын шүүлтүүрийн нарийн ширхэглэлтэй үнсний гадаад бүтэи, а- энгийн зургийн аппаратаар авсан, б- электрон микроскопоор авсан

Зарим эрдэмтэд нүүрсний шаталтын дагавар бүтээгдэхүүн нь жилд 600 сая тонноор хаягддаг бөгөөд үүнээс 500 сая тонн буюу $75-80 \%$-ийг нарийн ширхэгтэй үнс (fly ash) эзэлдэг бөгөөд дэлхийн дунджаар нийт үнсний 16\%-ийг ашигладаг гэж дурдсан байдаг [5]. Гэвч хамгийн сүүлийн үеийн тооцоогоор жилд 750 сая тонн үнс хаягддаг гэж үзсэн бөгөөд үүний 25 хувийг ахин ашигладаг байна $[6,7]$. Үнс нь хаягдаж буй хэмжээгээрээ дэлхийн 5 дахь том түүхий эдийн нөөц гэж тооцогддог [8]. Өөрөөр хэлбэл, цахилгаан станцын хаягдал үнс нь зайлшгүй ашиглах түүхий эд юм. Иймээс ч үнсний судалгаа нь хамгийн сонирхол татаж буй сэдвийн тоонд ордог.

АНУ-ын Шинжлэх ухааны мэдээллийн хүрээлэнгийн Томсон-РойтерсийнWeb of

\section{ТУУХИЙ ЭДИЙН СУДАЛГАА}

Химийн найрлагийн хувьд үнс нь хөнгөн цагаан, цахиур, төмөр болон кальцийн оксидыг хамгийн их хэмжээгээр агуулдаг. 2-p хүснэгтэнд дэлхийн бүс

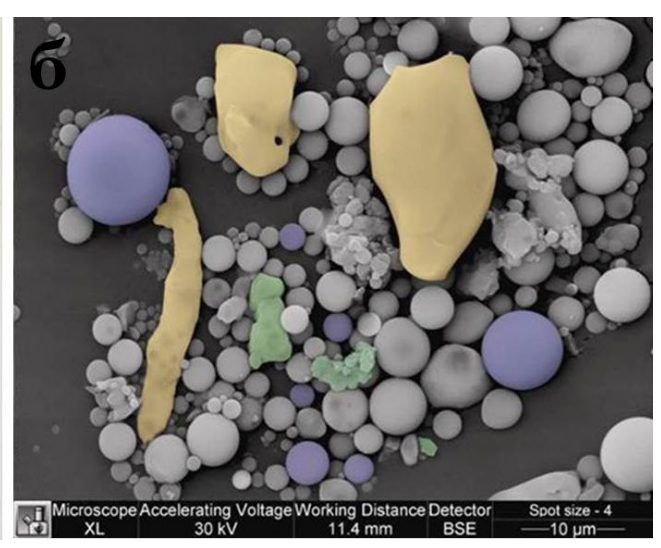

Knowledge болон Elsevier компанийн Scopus бүртгэлийн системүүдэд зөвхөн 2013 оны 1-ээс 9 сарын хугацаанд судалгааны сэдэвт нь үнс гэсэн үг орсон 1300 гаруй өгүүлэл бүртгэгдсэн байх бөгөөд жилд дунджаар 1500 орчим өгүүлэл энэ сэдвээр хэвлэгддэг. Гэхдээ энэхүу өгүүллүүдэд цахилгаан станцын хаягдал үнснээс гадна цагаан будааны хальс, тарианы сүрэл, ахуйн хаягдлыг шатаасан үнсний судалгаа ордогыг дурдах нь зүйтэй юм.

Энэхүу богино хэмжээний тойм өгүүлэлд цахилгаан станцын хаягдал үнсийг ямар чиглэлээр ашиглаж байгаа талаархи сүүлийн үед хийгдсэн судалгааг тоймлон Үзүүлэхээс гадна өөрсдийн хийж буй судалгааны ажлыг мөн харуулах болно.

нутгуудын цахилгаан станцын хаягдал үсний химийн найрлагыг дундачлан үзүүлэв. 
Дэлхийн бүс нутгуудад хаягдаж буй үнсний химийн дундаж найрлага [6].

\begin{tabular}{|c|c|c|c|c|c|}
\hline \multirow{2}{*}{ Нэгдэл } & \multicolumn{5}{|c|}{ Хязгаар (жин\%) } \\
\cline { 2 - 6 } & Европ & АНУ & БНХАУ & Энэтхэг & Австрали \\
\hline $\mathrm{SiO}_{2}$ & $28.5-59.7$ & $37.8-58.5$ & $35.6-57.2$ & $50.2-59.7$ & $48.8-66.0$ \\
\hline $\mathrm{Al}_{2} \mathrm{O}_{3}$ & $12.5-35.6$ & $19.1-28.6$ & $18.8-55.0$ & $14.0-32.4$ & $17.0-27.8$ \\
\hline $\mathrm{Fe}_{2} \mathrm{O}_{3}$ & $2.6-21.2$ & $6.8-25.5$ & $2.3-19.3$ & $2.7-14.4$ & $1.1-13.9$ \\
\hline $\mathrm{CaO}$ & $0.5-28.9$ & $1.4-22.4$ & $1.1-7.0$ & $0.6-2.6$ & $2.9-5.3$ \\
\hline $\mathrm{MgO}$ & $0.6-3.8$ & $0.7-4.8$ & $0.7-4.8$ & $0.1-2.1$ & $0.3-2.0$ \\
\hline $\mathrm{Na}_{2} \mathrm{O}$ & $0.1-1.9$ & $0.3-1.8$ & $0.6-1.3$ & $0.5-1.2$ & $0.2-1.3$ \\
\hline $\mathrm{K}_{2} \mathrm{O}$ & $0.4-4.0$ & $0.9-2.6$ & $0.8-0.9$ & $0.8-4.7$ & $1.1-2.9$ \\
\hline $\mathrm{P}_{2} \mathrm{O}_{5}$ & $0.1-1.7$ & $0.1-0.3$ & $1.1-1.5$ & $0.1-0.6$ & $0.2-3.9$ \\
\hline $\mathrm{TiO}_{2}$ & $0.5-2.6$ & $1.1-1.6$ & $0.2-0.7$ & $1.0-2.7$ & $1.3-3.7$ \\
\hline $\mathrm{MnO}$ & $0.03-0.2$ & - & - & $0.5-1.4$ & - \\
\hline $\mathrm{SO}_{3}$ & $0.1-12.7$ & $0.1-2.1$ & $1.0-2.9$ & - & $0.1-0.6$ \\
\hline ШЖХ & $0.8-32.8$ & $0.2-11.0$ & - & $0.5-5.0$ & - \\
\hline
\end{tabular}

Үнс нь химийн найрлага, шинж чанарынхаа дагуу ангилагдаж болно. Тухайлбал, бетонд хэрэглэгдэх цахилгаан станцын нарийн ширхэглэлтэй үнсний Америк болон Европын стандартууд байдаг байдгыг 3-p хүснэгтэнд тоймлон үзүүлэв. $[9,10]$.

3-р хүснэгт

Бетонд хэрэглэгдэх Үнсэнд тавигдах АНУ болон Европ-ын стандарт шаардлага

\begin{tabular}{|c|c|c|c|c|}
\hline Ангилал & $\mathrm{SiO}_{2}+\mathrm{Al}_{2} \mathrm{O}_{3}+\mathrm{Fe}_{2} \mathrm{O}_{3}(\%)$ & $\mathrm{SO}_{3}(\%)$ & Чийгшэл (\%) & ШЖХ (\%) \\
\hline \multicolumn{5}{|c|}{ ASTM C618 } \\
\hline $\mathrm{C}$ & $>50$ & $<5$ & $<3$ & $<6$ \\
\hline $\mathrm{F}$ & $>70$ & & & $<12$ \\
\hline \multicolumn{5}{|c|}{ EN 450-1 } \\
\hline A & $>70$ & $<3$ & $>25$ & $<5$ \\
\hline B & & & & $2-7$ \\
\hline $\mathrm{C}$ & & & & $4-9$ \\
\hline
\end{tabular}

Үнсний химийн найрлага нь антрацит төрлийн нүүрсийг шатаахад нүүрсэнд агуулагдах хольцоос хамаарах гардаг байна. Ашиглаж буй нүүрсний боловч нүүрсний төрлөөс мөн хамаардаг. Тухайлбал, Америкын $\mathbf{C}$ ангиллын үнс нь лигнит төрлийн нүүрсийг шатаахад төрлөөс хамаарч үнсний химийн найрлага өөрчлөгдөх хязгаарыг 4-p хүснэгтэнд харуулав.

үүсдэг бол $\mathbf{F}$ ангиллын үнс нь чулуун юмуу

4-р хүснэгт

Нүурсний төрөл, Үнсний химийн найрлагын харьц̧аа [11].

\begin{tabular}{|c|c|c|c|}
\hline Исэл, (жин \%) & Битумжсэн & Хагас битумжсжэн & Хүрэн нүүрс \\
\hline $\mathrm{SiO}_{2}$ & $20-60$ & $40-60$ & $15-45$ \\
\hline $\mathrm{Al}_{2} \mathrm{O}_{3}$ & $5-35$ & $20-30$ & $10-25$ \\
\hline $\mathrm{Fe}_{2} \mathrm{O}_{3}$ & $10-40$ & $4-10$ & $4-15$ \\
\hline $\mathrm{CaO}$ & $1-12$ & $5-30$ & $15-40$ \\
\hline $\mathrm{MgO}$ & $0-5$ & $1-6$ & $3-10$ \\
\hline
\end{tabular}




\begin{tabular}{|c|c|c|c|}
\hline $\mathrm{Na}_{2} \mathrm{O}$ & $0-4$ & $0-2$ & $0-6$ \\
\hline $\mathrm{K}_{2} \mathrm{O}$ & $0-3$ & $0-4$ & $0-4$ \\
\hline $\mathrm{SO}_{3}$ & $0-4$ & $0-2$ & $0-10$ \\
\hline ШХ & $0-15$ & $0-3$ & $0-5$ \\
\hline
\end{tabular}

Хаягдал үнс нь эрдэс зүйн найрлагынхаа хувьд 50-иас багагүй хувь нв аморф шилэн фазаас тогтох бөгөөд талст нэгдлийн хувьд голчлон кварц, муллит, хээрийн жонш, төмрийн оксидуудыг агуулдаг. Хаягдал үнсэнд мөн дутуу шатсан нүүрс зохих хэмжээгээр агуулагддаг байна. Энэхүу дутуу шатсан нүүрсийг үнсний массаас салган авч идэвхижүүлсэн нүүрс хэлбэрээр ашиглах боломжтой гэж зарим судлаачид дурдсан байдаг $[12,13]$.

Хэдийгээрнүүрснийүндсэнбүрэлдэх Үүнхэсэгньорганикгаралтайболовчоргани кбусэрдэсболонбагаагуулгатаймөртөдий (trace elements) хольцод байгалийн цацраг идэвхит элемент агуулагдаж болдог. ЭнэХүҮ цацраг идэвхит үндсэн элементүүдэд уран $(\mathrm{U})$, торий (Th) болон тэдгээрийн задралын бүтээгдэхүүнүүд тухайлбал, радии (Ra) болон радон (Rn) багтана. Хэдийгээр эдгээр элементүүд үнсэнд агуулагдах хүнцэл (As arsenic), селен (Se selenium) болон мөнгөн уснаас (Hg mercury) химийн хорны хувьд бага үйлчилгээтэй боловч үзүүлж болох цацрагийн нөлөө нь гол эрсдэлийг агуулж байдаг [14]. Нүүрсийгшатаасны дараахь үеийн цацрагийн үнэлгээ нь эх нүүрс болон шатаасны дараахь үнсэнд агуулагдах цацраг идэвхит элементийн хэмжээнээс хамаарна. АНУ-ын геологийн алба нь нүүрсэнд агуулагдах элементийн агуулгын талаархи хамгийн том мэдээллийн санг бүрдүүлсэн бөгөөд 2000 гаруй нүүрсний дээжинд агуулагдах ураны тархалтыг 4-p зурагт үзүүлэв [14].

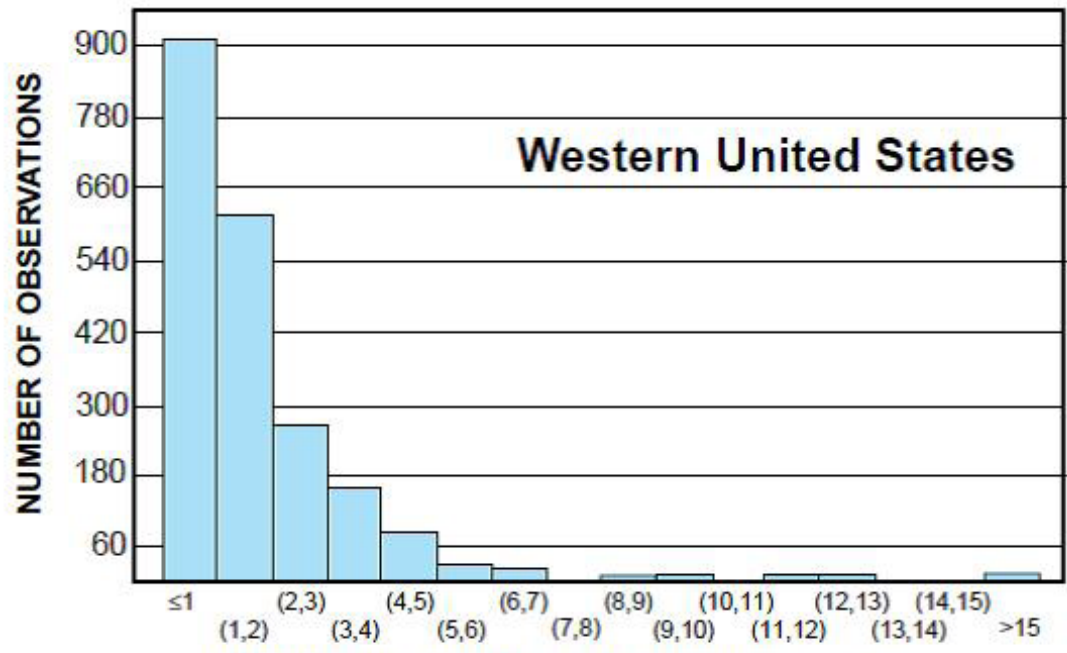

URANIUM CONCENTRATION IN WHOLE COAL (ppm)

4-р зураг. АНУ баруун мужуудад ориих нүҮрсэнд агуулагдах ичащрагийн хэмжээ [14].

Ихэнхи нүурсэнд агуулагдах цацрагийн хэмжээ нь 1-4 саяны нэг (ppm) концентрациас бага агуулгатай байна.
Ураны энэхүҮ агуулга нь ихэнхи чулуулаг болон хөрсөнд байдаг хэмжээтэй ижил байгааг 5-р зургаас харж болно. 


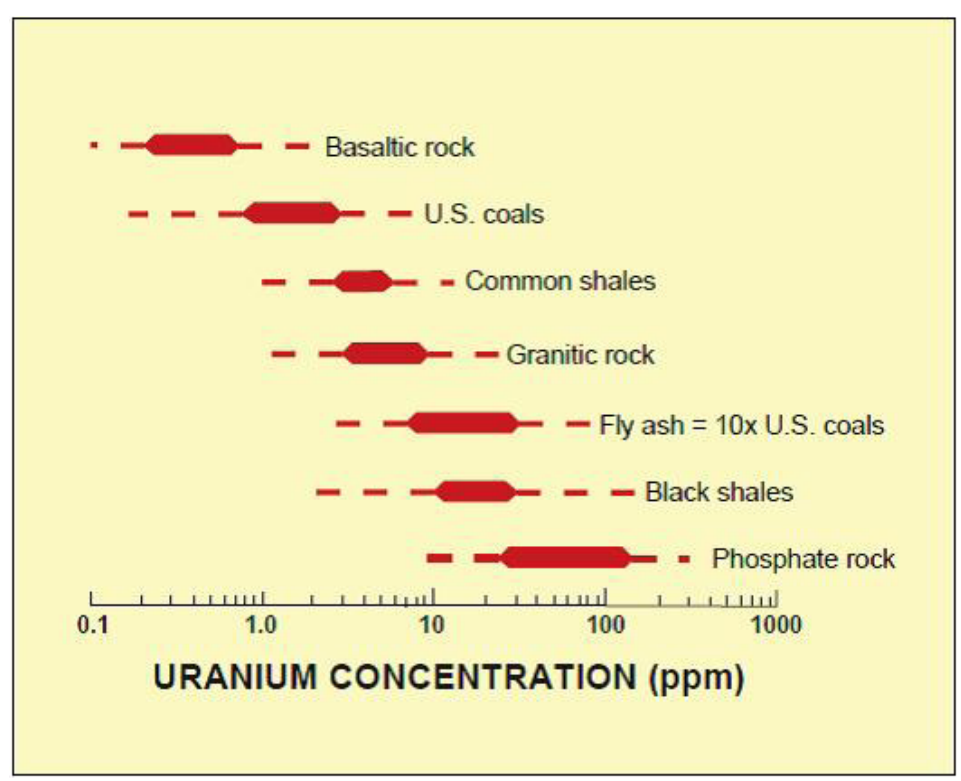

5-р зураг. НҮҮрс, хөрс, Үнс, чулуулгад агуулагдах ураны дундаж хэмжээ, [14].

Нүүрсэнд агуулагдах эрдэс хэсэг нь дунджаар нүүрсний 10\%-ийг эзэлдэг учраас үнсэнд агуулагдах цацраг идэвхит бодисын хэмжээ ойролцоогоор эх нүүрсэнд агуулагдах хэмжээнээс 10 дахин их байна. Өөрөөр хэлбэл үнсний цацрагийн хэмжээ нь нүүрснийхээс 10 дахин баяжсан байдаг. АНУ-ын геологийн албаны мэдээнд дурдсанаар торийн агуулга нь дундаж хэмжээгээрээ 1-4 саяны нэгд багтдаг бөгөөд энэ нь газрын цардаст агуулагдах дундаж хэмжээ болох ойролцоогоор 10 саяны нэг утгаас бага байна. Торийн агуулга нь 20 саяны нэгээс их нүүрс маш ховор байдаг байна. Нүүрсэнд агуулагдах уран болон түүний задралын бүтээгдэхүүнүүд нь нүүрсний органик хэсэг буюу гумины хүчилтэй холбоотой байдаг бол торий болон түүний задралын бүтээгдэхүүнүүд, калийн изотоп нь органик бус хэсэгтэй (үнсний матрикс) холбоотой байдаг байна [15].

\section{ХАЯГДАЛ ҮНСНИЙ ХЭРЭГЛЭЭ}

Хаягдал үнсийг цементийн түүхий эд юмуу нэмэлт болгон хэрэглэх нь одоогийн түвшинд ашиглагдаж буй хамгийн том хэрэглээ юм [17]. Нийт гарч буй үнсний
Нүүрсний цацраг идэвхит изотоп болон задралын бүтээгдэхүүн нь уг элементүүд нь нүүрсний органик болон органик бус хэсэгтэй холбогдож байгаагаас шалтгаалан өөр өөр байж болдог байна.

Үнсэнд агуулагдах цацраг нь тухайн түүхий эдийг ашиглахгүй байх үндэс болохгүй юм. Учир нь бидний хэрэглэж байгаа байгалийн хөрс болон чулуулгийг ашиглаж гаргасан материалуудад цацраг идэвхит ${ }^{238} \mathrm{U},{ }^{232} \mathrm{Th}$ төрлийн элемент болон калийн радио идэвхит изотоп болох ${ }^{40} \mathrm{~K}$ голчлон агуулагддаг. Ураны эрэмбийн задралд ${ }^{226} \mathrm{Ra}-$-гаас эхэлсэн задрал нь цацраг идэвхижлийн хувьд чухал ач холбогдолтой бөгөөд иймээс олон тохиолдолд ураныг биш радийг зааж өгсөн байдаг. Дэлхийн царцдаст агуулагдаж байгаа радий, торий калийн цацрагийн хэмжээ нь 40 Бк/кг, 40 Бк/кг ба 400 Бк/кг байдаг[16].

72\%-ийг цемент, бетоны үйлдвэрлэлд ашигладаг байна [18].

Цахилгаанстанцынүнсийгголчлонүнс энцөөрөмдхадгалаадгазартбулахзамаарза 
йлуулдагбайсанболовчөнгөрсөнзууны 30 аад оноосэхлэнбетонднэмэлтхэлбэрээрхо линусансангийнбүтээцэдашиглажэхэлжэ э.Тухайлбал, "Hungry horse" усан сангийн даланг АНУ-ын Montana муж улсад 19481953 онуудад 120000 тонн үнс ашиглаж барьсан. Мөн 1950-1970 онуудад 100 гаруй том хэмжээний далангийн барилгад үнсний агуулагдах хэмжээ нь 50 хүртэлхи хувийг эзлэх бетоныг ашиглажээ [19]. Англи улсад үнсний хольцтой бетоныг 1954 онд анх удаа Бридэлбэйний усан сан (Breadalbane dams) байгуулахад ашигласан байна. Үнсийг бетонд нэмэлтээр хийн барьсан дэлхийд нэртэй байгууламжид дэлхийн хамгийн өндөр барилга буюу Бурж Дубай цамхаг орно. Уг байгууламжийг өндөр бат бэхтэй бетон ашиглаж барихдаа 40\%-ийн үнсэн нэмэлт ашиглажээ [20].Өөрөөр хэлбэл, үнсийг цемент, бетонд нэмэлт хэлбэрээр ашиглах нь уламжлалт өргөн хэрэглэгддэг арга юм. Иймд үнсний уламжлалт бус хэрэглээг тодруулж байна.

\section{Үнсийг полимерийн үйлдвэрлэлд ашиглах Hb:}

Үнсийг полимерийн үйлдвэрлэлд ашиглах боломж нь харьцангуй бага судлагдсан сэдэв юм. Гол зарчим нь үнсний бөмбөлөг хэлбэрийн бүтцийг ашиглахад оршдог гэж дурдсан байна [21].Резин, поливинил хлорид (PVC), полиэтилен (PE), полипропилен (РP), полиэстер давирхай болон будгийн үйлдвэрлэлд үнсийг дүүргэгч болгон ашиглах боломж дурджээ[22]. Үнсний бөмбөлөг хэлбэр нь хамгийн бага талбайд хамгийн их эзэлхүүн эзлэх боломжийг олгон полимерийн тусгай шинж чанарыг сайжруулдаг байна. Бөмбөлөг хэлбэр нь мөн урсалтыг сайжруулан, халуунаар шахаж хэвлэх ажиллагааг хялбаршуулдаг гэж тэмдэглэгджээ. Резинд дүүргэгч болгон хэрэглэдэг шохойн чулуу болон каолинтиыг бөмбөлгөн хэлбэртэй үнсээр орлуулах Plastilдүүргэгчийн Өмнөд Африкт гарган авсан байна.

Үнсийг шингээгч (адсорбент) болгон ашиглах нь:
Хаягдал үнсийг шингээгч болгон ашиглах боломжийн талаархи хамгийн длэлгэрэнгүй тойм өгүүллийг Ванг, Вуй нар бичсэн байна [23]. ЭнэхүҮ тойм өгүүлэлд дурдсанаар хаягдал үнсийг шаталтын үед дэгдэх хүхэрлэг хий, азотын оксид NOx, мөнгөн ус, хийн хэлбэртэй органик нэгдлийг цэвэрлэх[24], хаягдал уснаас төрөл бүрийн хортой металл $\left(\mathrm{Cu}^{2+}, \mathrm{Pb}^{2+}\right.$, $\mathrm{Cd}^{2+}, \mathrm{Ni}^{2+}, \mathrm{Zn}^{2+}, \mathrm{Cr}^{3+}, \mathrm{Cr}^{6+}, \mathrm{Hg}^{2+}, \mathrm{As}^{3+}, \mathrm{As}^{5+}$, $\left.\mathrm{Cs}^{-}\right)$металлын төрлийн нэгдэл, органик бус анион болон органик будгийг зайлуулахад ашиглах судалгаа хийгдсэн байна [23, 25]. Бусад шингээгчидтэй харьцуулахад үнс нь эдийн засгийн хувьд илүү ашигтай шингээгчидтооцогдож байна. Үнсдангаараа шингээлтийн багтаамж харьцангуй бага юм. Үнсний шингээгчид хамгийн сайнаар нөлөөлж байгаа нэгдэл нь дутуу шатсан нүүрс юм. Гадаад улсуудад гарч буй хаягдал үнсний жингийн 1-10\% хүртэлхи хувьд дутуу шатсан нүүрс агуулагддаг гэж дурдагдсан байдаг нь шиэнгээлтийг сайжруулах үндэс болсон байна. Үнсний шингээлтиигсайжруулахын тулд химийн боловсруулалт хийх нь зохимжтойг тэмдэглэжээ [23].

Үнсийг цеолитын түүхий эд болгон ашиглах нь:

Үнсийг цеолит нийлэгжүүлэх түүхий эд болгох, гаргасан цеолитыг төрөл бүрийн шингээгч болон катализын зориулалтаар ашиглах нь хамгийн их сонирхол татсан сэдвийн нэг юм. Үнсний химийн найрлага, нийлэгжүүлэх нөхцөл зэргээс шалтгаалан цеолит $\mathrm{P}\left(\mathrm{Na}_{6} \mathrm{Al}_{6} \mathrm{Si}_{10} \mathrm{O}_{32} \cdot 12 \mathrm{H}_{2} \mathrm{O}\right)$,филипсит $\left(\mathrm{K}_{2} \mathrm{Al}_{2} \mathrm{Si}_{3} \mathrm{O}_{10} \cdot \mathrm{H}_{2} \mathrm{O}\right), \quad$ К-чабазит $\left(\mathrm{KAlSiO}_{4} \cdot 1.5 \mathrm{H}_{2} \mathrm{O}\right), \quad$ фаужасит $\left(\mathrm{Na}_{2} \mathrm{Al}_{2} \mathrm{Si}_{3.3} \mathrm{O}_{8.8} \cdot 6.7 \mathrm{H}_{2} \mathrm{O}\right)$, цеолит $\mathrm{A}$ $\left(\mathrm{NaAlSi}_{1.1} \mathrm{O}_{4.2} \cdot 2.25 \mathrm{H}_{2} \mathrm{O}\right)$, цеолит $\mathrm{X}$ $\left(\mathrm{NaAlSi}_{1.23} \mathrm{O}_{4.46} \cdot 3.075 \mathrm{H}_{2} \mathrm{O}\right)$, цеолит $\mathrm{Y}$ $\left(\mathrm{NaAlSi}_{2.43} \mathrm{O}_{6.86} \cdot 4.465 \mathrm{H}_{2} \mathrm{O}\right), \quad$ аналцим $\left(\mathrm{NaAlSi}_{2} \mathrm{O}_{6} \cdot \mathrm{H}_{2} \mathrm{O}\right), \quad$ гидроксисодалит $\left(\mathrm{Na}_{1.08} \mathrm{~A} \mathrm{l}_{2} \mathrm{~S} \mathrm{i}_{1.68} \mathrm{O}_{7.44} \cdot 1.8 \mathrm{H}_{2} \mathrm{O}\right)$, гидроксиканкринит $\left(\mathrm{Na}_{14} \mathrm{Al}_{12} \mathrm{Si}_{13} \mathrm{O}_{51} \cdot 6 \mathrm{H}_{2} \mathrm{O}\right)$ төрлийн цеолитуудыг нийлэгжүүлж байсан байна [2]. Үнснээс нийлэгжүүлсэн цеолит 
$\mathrm{X}(\mathrm{Na}-\mathrm{X})$ нь $\mathrm{Ni}^{2+}, \mathrm{Cu}^{2+}, \mathrm{Cd}^{2+}$ болон $\mathrm{Pb}^{2+}$ зэрэг хүнд металлуудыг шингээх чадвартайг илрүүлжээ [26]. Үнснээс нийлэгжүүлсэн 14 төрлийн цеолитыг ашиглан 3 валенттай хромын оксидыг уснаас зайлуулах боломжтойгтодорхойлонхамгийн оновчтой шингээлтийн горим тодорхойлогдсон байна [27]. Цеолит нийгжүүлэн хүнд болон хортой элементийг хаягдал уснаас зайлуулах судалгаа нь лабораторийн түвшинд төдийгүй хагас үйлдвэрлэлийн нөхцөлд мөн туршигдан батлагджээ [28]. Хагас үйлдвэрлэлийн нөхцөлд 1100 кг үнсийг тусгай реакторт боловсруулан 2924 Л бохирдсон уснаас хүнд болон хортой элементийг ялгаж чадсан байна. Өөрөөр хэлбэл, энэхүү ажил нь үйлдвэрлэл практикт туршигдсан гэж үзэж болох юм.

\section{Үнсийг керамикын түүхий эд болгон ашиглах нь:}

Үнс нь өөртөө $\mathrm{SiO}_{2}, \mathrm{Al}_{2} \mathrm{O}_{3}, \mathrm{CaO}$, $\mathrm{Fe}_{2} \mathrm{O}_{3}$ зэрэг оксидуудыг агуулж байдгаас шилэн керамик материалын түүхий эд болгох боломжтой гэж зарим судлаачид үзсэн байдаг [29]. Тэд эхлээд үнсэндээ хайлш үүсгэгч нэмэлт нэмэн $1500-1600^{\circ} \mathrm{C}$ температурт хайлуулжээ. Дараа нь хайлуулсан шилээ нунтаглан ахиж хэвлээд 900-1200 ${ }^{\circ}$ температурт талсжуулан шилэн керамик материал гарган авсан байна. Харин үнсэн дээр холбогч нэмэлт хийн хэвлээд 900-1300 ${ }^{\circ} \mathrm{C}$ температурт шатаан керамик биет гаргах боломжтой юм. Энэтхэгийн Жандаспур дахь Металлургийн төв лабораторид үнсийг ашиглан $100^{\circ} \mathrm{C}$ температурт өөрөө паалан үүсдэг шинэ төрлийн хананы хавтан болон галд тэсвэртэй тоосго гарган авч патентаар баталгаажуулсан байна [18].

\section{Үнсийг хөдөө ажс ахуйд ашиглах нь:}

Үнсийг хөдөө аж ахуйд хөрсний чанар сайжруулагчаар ашиглах боломжтой гэж зарим судалгаанд дурдагдсан байна[30, 31]. Ихэнхи үр тарианы ургалт хөрсний $\mathrm{pH}$ нь 6.5-7 байхад сайн явагддаг байна. Харин үнс нь хүчиллэг болон шүлтлэг аль нь ч байж болдог. Иймд хүчиллэг хөрсөнд шүлтлэг үнсийг цацахад нийт хөрсний $\mathrm{pH}$ ийг өсгөдөг. Энэ нь $\mathrm{Ca}, \mathrm{Na}, \mathrm{Al}$ болон $\mathrm{OH}$ ионуудын хөрсөнд шингэх боломжийг олгодог байна. Үнсийг хөдөө аж ахуйд ашиглах судалгаанд хэрэглэгдсэн түүхий эд нь кальцийн агуулга өндөртэй $(\mathrm{CaO}>15 \%)$ C ангиллын үнс байдаг. Үнсийг хөрсөнд нэмэхэд бүтэц нь сайжран, нягт нь буурах, хөрсний агааржилт нэмэгдэх, хатуу цардас үүсэхийг багасгах, бордоо болон шохойн хэрэглээг бууруулах зэрэг эерэг талууд ажиглагддаг. Гэхдээ зарим тэжээлийн бодисын уусалтыг багасгах сөрөг үзэгдэл мөн тэмдэглэгджээ [6].

Үнсийг геополимерийн түүхий эд болгон ашиглах нь:

Геополимер гэдэг нь хагас аморф, хөнгөн цагаант цахиурын үеэлсэн полимертэй төстэй бүтэцтэй нэгдэл юм. Үүнийг голчлон хөнгөн цагаант цахиурын түүхий эд буюу хаягдал үнсийг ашиглан гаргадаг. Сүүлийн жилүүдэд дэлхий нийтэд геополимерийн судалгаа нь хамгийн их сонирхол татаж буй халуун сэдвийн нэг болоод байгаагийн дээр олон тооны тойм өгүүлүүд хэвлэгдсэн байна [32-34]. Үнснээс гаргасан геополимер төрлийн материал нь шинжилгээ судалгааны түвшнээс хальж хагас үйлдвэрлэл, үйлдвэрлэлийн бүтээгдэхүүн болж Австралид E-Crete ${ }^{\mathrm{TM}}$ бетон нэрээр үйлдвэрлэгдэж байна [35]. Геополимерийн хамгийн гол хэрэглээ нь барилга, замын материал болох төрөл бүрийн бетоны үйлдвэрлэл юм. Геополимер бетон үйлдвэрлэхэд $F$ төрлийн буюу кальцийн оксидын $(\mathrm{CaO})$ агуулга багатай үнсийг ашиглахад тохиромжтой гэж үздэг $[36,37]$. Геополимер материал үйлдвэрлэх зарчмыг 6-р зургаар харуулж болно.

Үнсийг шүлтээр зуурахдаа жингийн 7580\%-д нь дүүргэгч нэмж өгвөл геополимер төрлийн бетон болох боломжтой юм. Геополимер төрлийн материалын бүтцийн үүсэлтийг түргэсгэхийн тулд дунджаар 60$80^{\circ} \mathrm{C}$ температурт тодорхой хугацаагаар (24 цаг хүртэл) бэхжүүлэх нь тохиромжтой юм. 


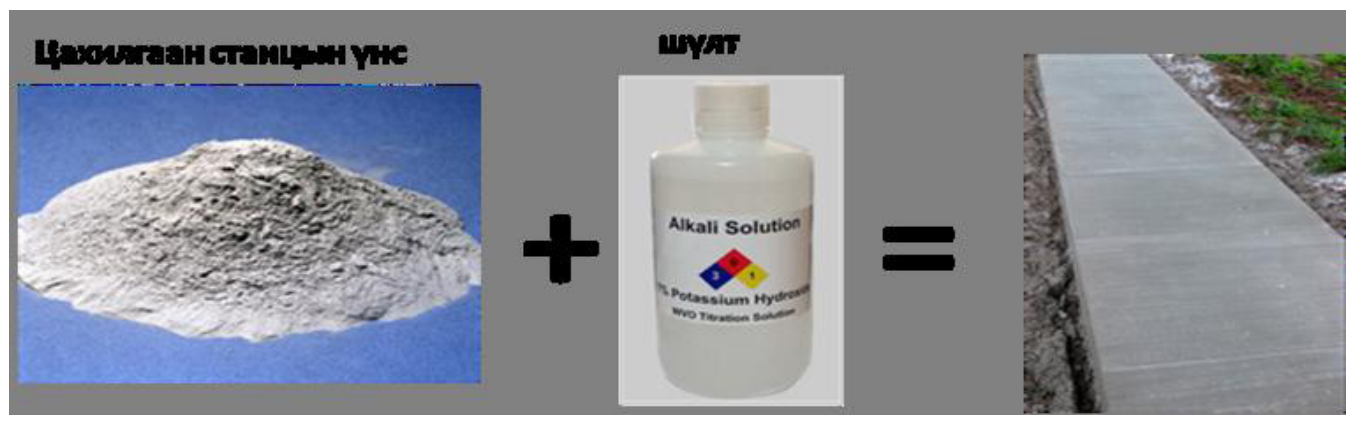

6-р зураг. Геополимер төрлийн материал гаргах ерөнхий зарчим

\section{МОНГОЛ УЛСАД ДУЛААНЫ ЦАХИЛГААН СТАНЦЫН ҮНСИЙГ АШИГЛАЖ БУЙ СУДАЛГААНЫ ҮР ДУНГЭЭС}

Монгол улсад дулааны цахилгаан станцынүнсийгашиглахоролдлогоөнгөрсөн зууны 70-аад оны үеэс эхэлсэн болотой. Тэр үед анх бетонон блокны цементийн зарим хэсгийг үнсээр орлуулах туршилт хийгдэж байсан байна. Мөн Дархан хотын цахилгаан станцын үнсийг керамзитын шаварт 30\% нэмэн хурдавчилсан горимоор шатааж, хөргөлтийн үед $800-700^{\circ} \mathrm{C}$-ийн үед 15 минут бариулан талсжуулж А ангилалд багтах керамзит гарган авах судалгаa 1980-аад оны сүүлээр хийгджээ [38]. Манай улсад хийгдэж буй судалгаанд үнсшаарганы холимогийг бетоны үйлдвэрлэлд ашиглахад зохих анхаарал тавьж тавьж байсан байна. Тухайлбал, шохой $5 \%$, цемент 45\%, 3-р цахилгаан станцын үнс 50\% бүхий хольц дээр 3-5\% хөнгөнцагааны нунтагийг савангийн уусмалаар зуурч хөөлгөгч болгон хэрэглээд $90^{\circ} \mathrm{C}$ темп?ратурт уураар 8 цаг жигнэсэн автоклавын бус сэвсгэр бетоны бат бөх 28 өдрийн дараа 600, 1000

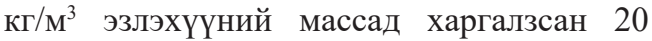
болон 30 кгс/см² байсан байна [39].Үнсийг барилгын материал, тухайлбал, керамик, бетоны үйлдвэрлэлд ашиглах туршилт, үйлдвэрлэлийн ажил нь 1986 онд Монгол улсад анх удаa "Барилгын материалд хэрэглэх дулааны цахилгаан станцын үнс"-ний стандартыг гаргах үндэсийг бий болгосон бололтой [40]. ЭнэХүү стандартад үнсийг төрөл зүйлээр хуваагаагүй,зөвхөн үнс нэрээр оруулсан байна. Улаанбаатар хотод одоогоор ажиллаж байгаа дулааны 3-н цахилгаан станцаас зөвхөн 4-p цахилгаан станц л үнсийг утаанаас ялгах шүүлтүүрээр тоноглогдсон бөгөөд бусад цахилгаан станцаас нарийн ширхэгт үнсийг ялган авах боломжгүй юм. Иймээс MNS 3298-86 стандартыг цахилгаан станцын шааргад зориулагдсан стандарт гэж үзэж болох юм. Харин манай улсад мөрдөгдөж буй портланд цементийн стандартад заасны дагуу цементийн үйлдвэрлэлд зөвхөн нарийн ширхэглэлтэй цахилгаан шүүлтүүрийн үнсийг хэрэглэх ёстой [41]

ШУА-ийн Хими, хими-технологийн хүрээлэнгийн Материалсудлалтехнологийн лабораторид 2010 оноос Монгол орны цахилгаан станцын үнсийг иж бүрнээр ашиглах туршилт судалгааны ажил хийгдэж байна [42].Улаанбаатарын 4-р цахилгаан станцын хаягдал Багануур болон Шивээовоогийн нарийн ширхэглэлтэй үнс нь ASTM ангиллар C бүлгийн үнсэнд багтаж байна. Манай лабораторид хийгдсэн хаягдал үнсийг ашиглан хортой элементийг шингээх чанар сайтай цеолит болон геополимер төрлийн барилга, замын материал гарган авах судалгаa, томсгосон туршилтын ажлын үр дүн эрдэм шинжилгээний хуралд хэлэлцэгдэн, мэргэжлийн сэтгүүлүүдэд хэвлэгдээд байна [43-47]. Манай лабораторид хийгдэж буй судалгааны дүнгээс харахад үнсний химийн найрлага, цацраг идэвхижлийн тогтворгүй байдал нь 
бүтээгдэхүүний технологи боловсруулахад хүндрэл өгөхөөр байна. Жишээ болгон Улаанбаатарын 4-p цахилгаан станцаас
2010, 2011, 2013 онуудад авсан Багануурын нүүрсний үнсний химийн найрлагын өөрчлөлтийг авч үзье (5-р хүснэгт).

Багануурын нүҮрсний Үнсний химийн найрлагын өөрчлөлт

5-р хүснэгт

\begin{tabular}{|c|c|c|c|c|c|c|c|c|c|c|c|c|c|}
\hline $\mathrm{Y}$ & $\mathrm{SiO}_{2}$ & $\mathrm{Al}_{2} \mathrm{O}_{3}$ & $\mathrm{Fe}_{2} \mathrm{O}_{3}$ & $\mathrm{CaO}$ & $\mathrm{MgO}$ & $\mathrm{MnO}$ & $\mathrm{SO}_{3}$ & $\mathrm{~K}_{2} \mathrm{O}$ & $\mathrm{SrO}$ & $\mathrm{TiO}_{2}$ & $\mathrm{Na}_{2} \mathrm{O}$ & $\mathrm{P}_{2} \mathrm{O}_{5}$ & $\begin{array}{c}\text { ШЖX, } \\
\%\end{array}$ \\
\hline $\begin{array}{c}\text { Багануур, } \\
2010\end{array}$ & 53 & 16.4 & 8.85 & 15.5 & 1.81 & 0.17 & 1.32 & 1.67 & 0.2 & 0.826 & - & - & 1.05 \\
\hline $\begin{array}{c}\text { Багануур, } \\
2011\end{array}$ & 55.75 & 13.82 & 10.43 & 14.24 & 1.67 & 0.32 & 0.83 & 1.325 & 0.12 & 0.41 & 0.11 & 0.03 & 0.94 \\
\hline $\begin{array}{c}\text { Багануур, } \\
2013\end{array}$ & 51.18 & 13.02 & 14.9 & 14.47 & 1.74 & 0.53 & 0.61 & 1.34 & - & 0.51 & 0.21 & 0.11 & 1.07 \\
\hline
\end{tabular}

Энэхүу хүснэгтээс харахад нэг орд газрын нүүрсний үнсний химийн найрлага нь дээж авах хугацаанд $0.1-6 \%$ хүртэл хязгаарт өөрчлөгдөж байна. ЭнэхүY өөрчлөлтөөс үҮдэн дүгнэлт хийхэд, үнсийг ашиглан гаргаж буй бүтээгдэхүүн нь химийн найрлагын өчүүхэн өөрчлөлтөнд ч мэдрэмтгий байвал тогтвортой ашиглагдах технологи боловсруулах боломжгүй юм.
Өөрөөр хэлбэл, химийн найрлагынтодорхой өөрчлөлт нь гаргасан бүтээгдэхүүний шинж чанарт аль болох бага өөрчлөлт үзүүлэх шаардлагатай юм.

Цеолит нийлэгжүүлэх судалгаа

Улаанбаатарын 4-p цахилгаан станцын Багануурын үнсийг ашиглан цеолит нийлэгжүүлэх судалгаа явуулсан туршилтын дарааллыг 7-р зурагт үзүүлэв.

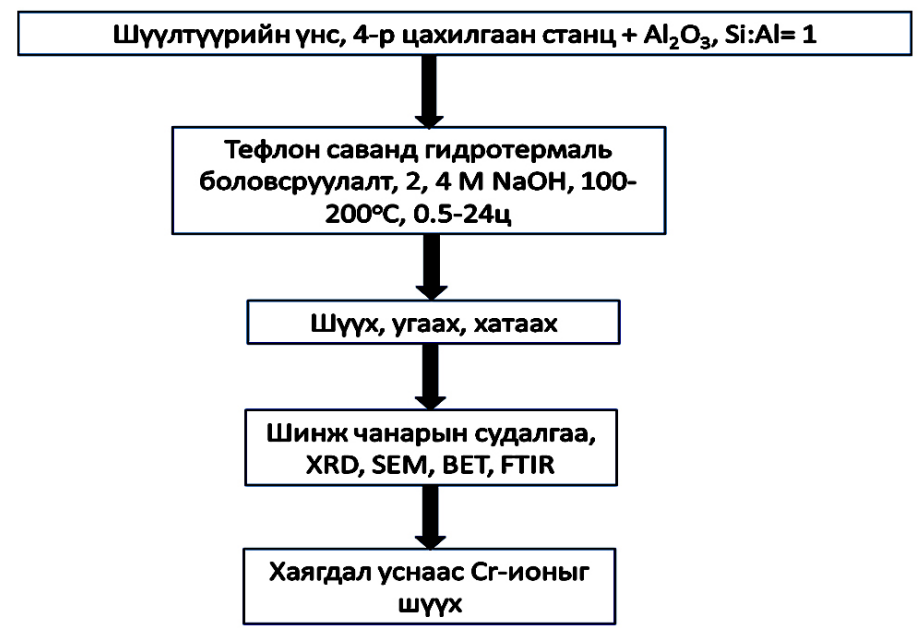

7-р зураг. Багануурын нүҮрсний Үнснээс цееолит нийлэгжүүлэх технологийн схем

Туршилтанд бэлтгэсэн холимгийг 150 дараахь дээжний Рентгенграммыг 8 -р болон $200^{\circ} \mathrm{C}$ температурт боловсруулны зүурагт харууллаа. 


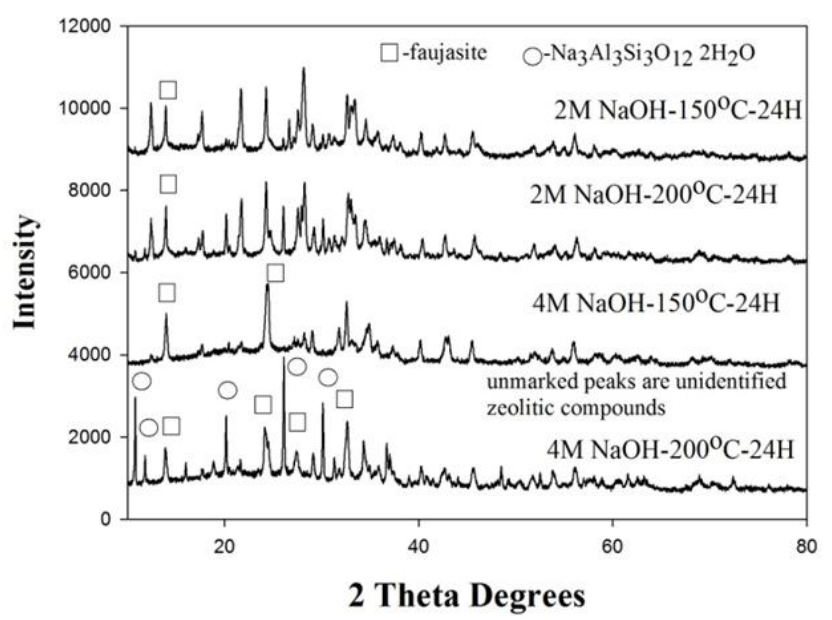

8-р зураг. 2 болон 4М концентрацитай шүлтээр 150, $200^{\circ} \mathrm{C}$ температурт 24 иаг боловсруулсан дээжний Рентгенграмм

ЭнэхүY Рентгенограммын зургас $\left.\mathrm{Al}_{7} \mathrm{Si}_{17} \mathrm{O}_{48}\right] \cdot 32\left(\mathrm{H}_{2} \mathrm{O}\right)$ болон натрийн цеолит харахад цеолитын төрлийн нэгдлийн $\left(\mathrm{Na}_{3} \mathrm{Al}_{3} \mathrm{Si}_{3} \mathrm{O}_{12} \cdot 2 \mathrm{H}_{2} \mathrm{O}\right)$ нь үндсэн талст фазыг талсжилтанд боловсруулалтын температур бүрдүүлж байна. Энэхүү нийлэгжүүлсэн болон шүлтийн концентраци чухал нөлөө цеолитын гадаад морфологийг 9-р зурагт үзүүлж байна. Фаужасайт $\left(\mathrm{Na}_{2}, \mathrm{Ca}, \mathrm{Mg}\right)_{3.5}[\quad$ Үзүүлэв.

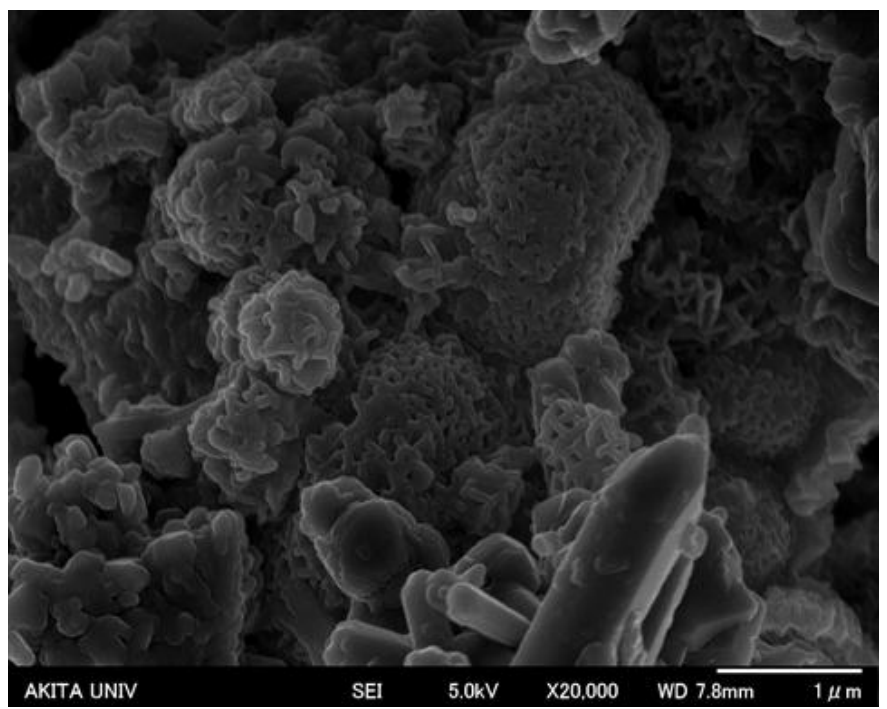

9-р зураг. $200^{\circ} \mathrm{C}$ температурт 24 иагийн тури нийлэгжүүлсэн иееолитын морфологи

Нийлэгжүүлсэн цеолитыг аван хромын давс зориуд хольж бэлтгэсэн устай $1 / 100$ харьцаагаар холин 1 цаг хутган тэнцвэрийн нөхцөлд хүргэсэн холмигоос хромын ионыг шингээх чадварыг тогтоосон үр дүнгээс харахад цеолит үүссэн дээжний хромын шингээлт 45\%-иар сайжирсан байв.

Геополимер төрлийн материал гаргаи авах судалгаа

Манай лабораторид 4-р цахилгаан станцын Багануур, Шивээ-овоогийн үнс, 4-p цахилгаан станцын үнсэн сангийн үнс, 
3-р цахилгаан станц, Дархан, Эрдэнэтийн цахилгаан станцын үнсэн сангийн үнсийг ашиглан геополимер төрлийн барилга, замын материал үйлдвэрлэх судалгааг явуулсны үндсэн дээр 4-p цахилгаан станцын цахилгаан шүүлтүрийн нарийн ширхэглэлтэй Багануурын үнс нь геополимер төрлийн зуурмаг, бетон үйлдвэрлэхэд хамгийн тохиромжтой болохыг тогтоосон юм. Гарган авсан

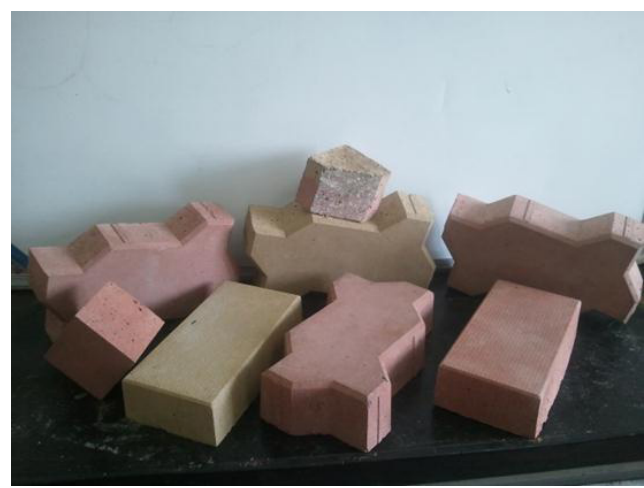

10-р зураг. Геополимер төрлийн бетон, хөнгөн бетон

Багануурын үнсийг ашиглаж гаргасан геополимер төрлийн бетоны хүйтэн тэсвэрлэлт нь 40 циклээс илүу байсныг тогтоосон. Туршилт явуулах үед цаг хугацааны хавчигдлаас шалтгаалан 40 циклийн дараа туршилтыг зогсоосон боловч бетонд ямар нэгэн өөрчлөлт

геополимер төрлийн барилга, замын материалын бат бөхийн үзүүлэлт нь 300 кг/ $\mathrm{cm}^{2}$-аас илүү байгаа нь стандартад тавигдах шаардлагыг хангаж байна.

Туршилтаар гарган авсан геополимер төрлийн нүх сүвэрхэг хөнгөн бетон болон зам барилгын өнгөлгөөний тоосго хэлбэрээр ашиглах боломжтой бетоны зургийн доор үзүүлэв (10-р зураг).

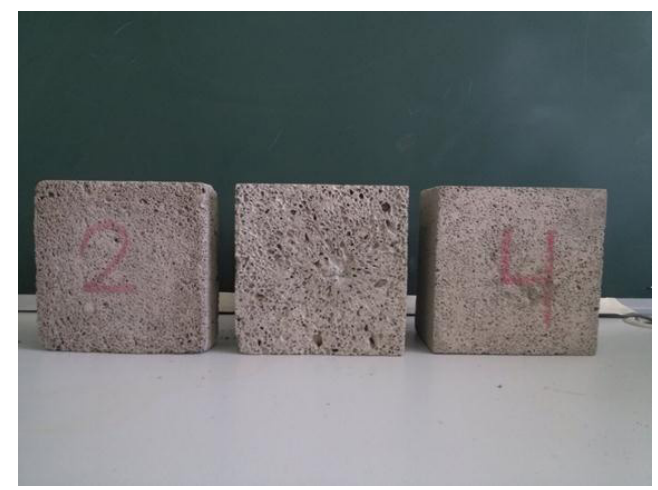

ажиглагдаагүй.

Манай улсад үнсийг үйлдвэрлэлийн зориулалтаар ашиглахад чухал ач холбогдолтой гэгддэг цацрагын үзүүлэлт, уг үнсийг ашиглаж хийсэн бетон бүтээгдэхүүний цацрагийн идэвхижлийг 6-р хүснэгтэнд үзүүлэв.

6-р хүснэгт

Багануурын Үнс, Үнсээр хийсэн бетоны цуачраг идэвхижил

\begin{tabular}{|c|c|c|c|c|c|}
\hline \multirow{2}{*}{ № } & \multirow{2}{*}{ Үнс } & \multicolumn{3}{|c|}{$\begin{array}{c}\text { Изотопын идэвхижлийн } \\
\text { концентраци, Бк/kг }\end{array}$} & $\begin{array}{c}\text { Радийн } \\
\text { эквивалент, } \\
\text { Бк/kг }\end{array}$ \\
\cline { 3 - 5 } & Багануур, 2011 & 242.4 & 31.1 & 381.6 & 314.4 \\
\hline 1 & $\mathrm{~A}_{\mathrm{Ra}-226}$, & $\mathrm{A}_{\mathrm{Th}-232}$, & $\mathrm{A}_{\mathrm{K}-40}$, & 129 \\
\hline 2 & Багануур 2011 үнсээр хийсэн бетон & 37.8 & 15.6 & 831.4 & 1328.2 \\
\hline 3 & Багануур, 2013 & 1257.6 & 27.3 & 420.9 & 195.7 \\
\hline 4 & Багануур 2013 үнсээр хийсэн бетон & 119.2 & 13.1 & 697.9 & \\
\hline
\end{tabular}

Барилгын материал болон хэрэглэгдэж байгаа бүтээгдэхүүний цацраг идэвхижлийн Радийн эквивалент нь 370 Бк/kг-аaс бага байх шаардлагатай байдаг Хэдийгээр 2013 онд авсан Багануурын үнсний цацраг идэвхижил нь 2011 онд авсныхаас 4 дахин их байгаа боловч энэ үнсийг ашиглаж хийсэн бетоны цацраг идэвхижил нь стандартын үзүүлэлтийг бүрэн хангаж байна. Учир нь бетон үйлдвэрлэхийн тулд 
нийт түүхий эдийн жингийн 75-80\%-д нь цацраг идэвхижил багатай хайрга юмуу дайргыг нэмдгээс эцсийн бүтээгдэхүүний цацраг идэвхижил буурдаг байна.

\section{ДҮГНЭЛТ}

Дулааны цахилгаан станцын үнс нь дэлхий нийтээр өргөн ашиглаж буй үнэт түүхий эд юм. Цахилгаан станцын шүүлтүүрийн нарийн ширхэглэлтэй үнс нь хэрэглээний чанараараа ашиглахад хамгийн тохиромжтой. Цахилгаан станцын үнсний хими, эрдэс зүйн найрлага болон гадаад хэлбэрньашиглахсалбар,хэрэглээнийшинж чанарыг тодорхойлно. Улаанбаатарын 4-р цахилгаан станцын шүүлтүүрийн нарийн

ширхэглэлтэй Багануурын үнсийг ашиглан фаужасайт төрлийн цеолит нийлэгжүүлэх боломжтой.

Багануурын үнс нь геополимер төрлийн материал гарган авахад хамгийн тохиромжтой байна. Гарган авсан материалын бат бөх болон цацрагийн үзүүлэлт нь хэрэглээний шаардлагыг хангаж байна.

\section{ТАЛАРХАЛ}

Монгол орны дулааны цахилгаан станцын үнсний нарийвчилсан судалгаа үнсээр төрөл бүрийн бүтээгдэхүүн хий боломжийг тогтоох эрдэм шинжилгээний ажил нь Шинжлэх ухаан технологийн төсөл,

сэдэвт ажил, ШУА-ийн судалгааны грант, Залуу докторын судалгааны грантаар санхүүжигдсаныг талархан тэмдэглэж байна.

\section{Ашигласан бүтээлийн жагсаалт}

1. http://www.the-colosseum.net/idx-en.htm, 2012 оны 9 сард хандсан.

2. V.K.Jha, M.Matsuda, M.Miyake, Resource recovery from coal fly ash waste: an overview study, Journal of the Ceramic society of Japan, 116 [2] 167-175, 2008

3. http://www.worldcoal.org/coal/uses-of-coal/coal-electricity/, 2012 оны 9 сард хандсан.

4. S.V.Vassilev, C.G.Vassileva, Occurrence, abundance and origin of minerals in coals and coal ashes, Fuel processing technology, 48 (1996) 85-106)

5. Ahmaruzzaman, A review on the utilization of fly ash, Progress in Energy and Combustion Science 36, 327-363, (2010)

6. R.S.Blissett, N.A.Rowson, A review of the multi-component utilisation of coal fly ash, Fuel 97, $1-23,(2012)$

7. S.Wang, Application of solidash based catalysts in heterogeneous catalysis, EnvironmentalScience and Technology,42, 7055-63, (2008)

8. A.B.Mukherjee, B.Zevenhoven, P.Bhatttachaya, K.S.Sajwan, R.Kikuchi, Mercury flow via coal and coal utilization by-products: a global perspective, Resource Conservation and Recycling, $52,571-591,(2008)$

9. ASTM C618-12, Standard specification for coal fly ash and raw calcined natural pozzolan for use in concrete

10. EN 450-1-2009, Fly ash concrete, Part 1. Definition, specifications and conformity criteria

11. J.F.Meyers, P.Raman, S.K.Bernadette, Fly ash. A highway construction material. Federal highway administration, Report No.FHWA-IP-76-16, Washington DC (1976)

12. J.J.Li, J.Cui, N.Q.Zhao, C.S.Shi, X.W.Du, The properties of granular activated carbons prepared from fly ash using different methods, Carbon 44, 1298-1352, (2006)

13. B.Rubio, M.T.Izquierdo, M.C.Mayoral,M.T.Bona, J.M.Andres, Unburnt carbon from coal fly ashes as a precursor of activated carbon for nitric oxide removal, Journal of Hazardous Materials $143,561-566,(2007)$

14. Radioactive elements in coal and fly ash: Abundance, forms and envirobmental significance, US geopological survey fact sheet FS-163-97

15. C.Papastefanou, Radioactivity of coals and fly ashes, Journal of radioanalytical and nuclear chemistry, 275, 29-35, (2008)

16. Radiological Protection Principles concerning the Natural Radioactivity of Building Materials, 
Radiation protection 112, 1999 Directorate-General Environment, Nuclear Safety and Civil Protection

17. Gonzбlez A, Navia R, Moreno N. Fly ashes from coal and petroleum coke combustion: current and innovative potential applications. Waste management research, 27, 976-87, (2009)

18. S.Kumar, Lecture on "Fly ash: challanges and oppurtunity" on 20th Sept 2012, organised by Indian Ceramic Society, Jamshedpur Chapter

19. R.S.Kalyoncu, D.W.Olson, Coal combustion products, U.S. Geological Survey, Fact Sheet 07601

20. W.F.Baker, D.S.Korista, L.C.Novak, Burjdubai: engineering the world's tallest building, Struct. Design Tall Spec. Build. 16, 361-375, (2007)

21. H.W.Nugteren, Coal fly ash: from waste to industrial product, Part. Part. Syst. Charact. 24, 49-55, (2007)

22. H. W. Nugteren, R. A. Kruger, Fly Ash as a replacement for mineral fillers in the polymer industry. Worldof coal ash, Lexington, Kentucky, USA (WOCA) 2005, (on CD).

23. S.Wang, H.Wu, Environmental-benign utilisation of fly ash as low-cost adsorbents, Journal of Hazardous Materials B136, 482-501, (2006)

24. A. Peloso, M. Rovatti, G. Ferraiolo, Fly ash as adsorbent material fortoluene vapours, Resour. Conserv. 10,211-220,(1983)

25. R.S.Iyer, J.A.Scott, Power station fly ash - a review of value-added utilization outside of the construction industry, Resources, Conservation and Recycling, 31, 217-228, (2001)

26. V.K.Jha, M.Nagae, M.Matsuda, M.Miyake, Zeolite formation from coal fly ash and heavy metal ion removal characteristics of thus-obtained Zeolite $\mathrm{X}$ in multi-metal systems, Journal of Environmental Management, 90, 2507-2514, (2009)

27. D.Wu, Y.Sui, S.He, X.Wang, C.Li, H.Kong, Removal of trivalent chromium from aqueous solution by zeolite synthesized from coal fly ash,Journal of Hazardous Materials, 155, 415423,(2008)

28. X.Querol, J.C.Umana, F.Plana, A.Alastuey, A.Lopez-Soler, A.Medinaceli, A.Valero, M.J.Domingo, E.Garcia-Rojo, Synthesis of zeolites from fly ash in a pilot plant scale. Examples of potential environmental applications, International ash symposium, University of Kentucky, 1999, Paper 12

29. M.Erol, S.Кьзьkbayrak, A.Ersoy-Meriзboyu, Comparison of the properties of glass, glassceramic and ceramic materials produced from coal fly ash. Journal of Hazardous Materials, 153, 418-25, (2008)

30. S.Jala, D.Goyal, Fly ash as a soil ameliorant for improving crop production - areview. Bioresour Technol, 97, 1136-47, (2006).

31. V.C.Pandey, N.Singh, Impact of fly ash incorporation in soil systems. Agric Ecosyst Environ, 136,16-27, (2010)

32. Komnitsas, K., Zaharaki, D., Geopolymerisation: a review and prospects for the minerals industry. Minerals Engineering 20, 1261-1277, (2007)

33. Duxson, P., Fernondez-Jimŭnez, A., Provis, J.L., Lukey, G.C., Palomo, A., Van Deventer, J.S.J.,. Geopolymer technology: the current state of the art. Journal of Materials Science 42, 2917-2933, (2007)

34. F.Pacheco-Torgal, Z.Abdollahnejad, A.F.Camxes, M.Jamshidi, Y.Ding, Durability of alkaliactivated binders: A clear advantage over Portland cement or an unproven issue?, Construction and Building Materials 30, 400-405, (2012)

35. J.S.J.van Deventer, J.L.Provis, P.Duxson, Technical and commercial progress in the adoption of geopolymer cement, Minerals Engineering 29, 89-104, (2012)

36. F.Skvбra, T.JHlek, L.Kopeckэ, Geopolymer materials based on fly ash, Ceramics - Silikбty 49 (3) 195-204 (2005)

37. Hardjito H, Rangan RV, Development and properties of low-calcium fly ash based geopolymer concrete, Research Report GC1, Faculty of Engineering, Curtin University of Technology, Perth, Australia 2005

38. Ц.Жадамбаа, Силикат, керамик материалыг нам температурт шатааж гарган авах онол ба технологийн үндэс, ШУТИС-ийн Манай эрдэмТэд цуврал, 441x, ШУТИС-ийн хэвлэл, Улаанбаатар 2004

39. О.Батмөнх, Ус бага шаардах холимог барьцалдуулагчийн онолын үндэс, бетоны технологи, ШУТИС-ийн Манай эрдэмТэд цуврал, 279x, ШУТИС-ийн хэвлэл, 
Улаанбаатар 2004

40. MNS 3297-86, Барилгынматериалдхэрэглэхдулааныцахилгаанстанцынүнс, Монгол улсын стандарт

41. MNS 974-2008, Портланд цемент, техникийн шаардлага, Монгол улсын стандарт

42. J.Temuujin,Characterisation and utilisation of coal combustion by products in Mongolia, in Fly Ash: Chemical Composition, Sources and Potential Environmental Impacts, Edited by P.K.Sarker, Chapter 6, Nova Science Publishers, New York, ISBN: 978-1-62948-044-2 (2013)

43. J.Temuujin, Preparation of zeolitic compounds from class $\mathrm{C}$ fly ash and its characterisation, 5th Asian Particle Technology Symposium APT-2012, July 2-5, 2012, Singapore, Conference Proceedings pp.125-130, ISBN: 978-981-07-2518-1:: doi:10.3850/978-981-07-2518-1 083

44. J Temuujin,W.Rickard, A.Van Riessen, Characterisation of various coal combustion products from Mongolian thermal power stations and their application for preparation of geopolymers and zeolitic compounds, 26th International Mineral Processing Congress, September 2428, 2012, New Delhi, India, (invited keynote lecture), Conference Proceedings, Paper 1136, pp.5455-5461

45. J.Temuujin, W.Rickard, A.van Riessen, Characterisation of various fly ashes for preparation of Geopolymers with advanced applications, Advanced Powder Technology, 24, 495-498, (2013)

46. J.Temuujina, A.Minjigmaaa, Ts.Zolzayaa, B.Davaabal, Preparation and characterisation of geopolymer type paste and concrete from high calcium Mongolian fly ashes, Transactions of the Indian Ceramic Society, (submitted for publications, 2013)

47. J.Temuujin, A.Minjigmaa, B.Davaabal, U.Bayarzul, Ankhtuya, K.J.D.MacKenzie, Sustainable utilization of fly ashes for alkali activated materials preparation, (submitted for publication, 2013) 